\title{
Short Communication BRAF mutations in non-Hodgkin's lymphoma
}

\author{
JW Lee', NJ Yoo', YH Soung', HS Kim', WS Park', SY Kim', JH Lee', JY Park', YG Cho', CJ Kim', YH Ko², \\ SH Kim', SW Nam', JY Lee' and SH Lee*,I \\ 'Department of Pathology, College of Medicine, The Catholic University of Korea, 505 Banpo-dong, Socho-gu, Seoul I 37-70I, Korea; ${ }^{2}$ Department of \\ Diagnostic Pathology, Samsung Medical Center, Sungkyunkwan University, Seoul I 35-7 I0, Kored
}

Ras proteins control signalling pathways that are key regulators of several aspects of normal cell growth and malignant transformation. $B R A F$, which encodes an RAF family member in the downstream pathway of RAS, is somatically mutated in a number of human cancers. The activating mutation of BRAF is known to play a role in tumour development. As there have been no data on the BRAF mutation in non-Hodgkin's lymphoma (NHL), we analysed the genomic DNAs from $164 \mathrm{NHLs}$ by polymerase chain reaction (PCR)based single-strand conformation polymorphism (SSCP) for the detection of somatic mutations of BRAF (exons II and I5). Overall, we detected BRAF mutations in four NHLs (2.4\%). Whereas most BRAF mutations in human cancers involved V599 of BRAF, all of the four BRAF mutations in the NHLs involved other amino acids (one G468A, two G468R and one D593G). To our knowledge, this is the first report on BRAF mutation in NHL, and the data indicate that BRAF is occasionally mutated in NHL, and suggest that BRAF mutation may contribute to the tumour development in some NHLs.

British Journal of Cancer (2003) 89, 1958-1960. doi:10.1038/sj.bjc.660 I37I www.bjcancer.com

(c) 2003 Cancer Research UK

Keywords: mutation; BRAF; RAS; non-Hodgkin's lymphoma; oncogene

The activated RAS proteins excite the mitogen-activated protein (MAP) kinase pathway (RAS-RAF-MEK-ERK-MAP kinase pathway) by recruiting the cytosolic protein RAF (Downward, 2003). RAF gene family consists of three members (ARAF1, BRAF and $R A F 1$ ), each encoding serine/threonine kinases that are regulated by binding to RAS. RAS - RAF-MEK - ERK - MAP kinase pathway plays a critical role in cell proliferation, and is frequently activated in cancer cells. For example, approximately $10-20 \%$ of all human tumours contain mutated versions of RAS proteins (Bos, 1989). Recently, Davies et al (2002) identified somatic mutations of $B R A F$ in $66 \%$ of malignant melanomas and at a lower frequency in a wide range of human cancers. So far, all $B R A F$ mutations have been reported within two kinase domains (G-loop and activation segment domains), and the most common mutation is a single substitution, V599E (Brose et al, 2002; Davies et al, 2002; Naoki et al, 2002; Rajagopalan et al, 2002; Yuen et al, 2002; Pollock et al, 2003; Satyamoorthy et al, 2003). Mutated BRAF proteins have elevated kinase activity and transforming activity in NIH3T3 cells (Davies et al, 2002). Furthermore, RAS function is not required for the growth of cancer cell lines with the V599E mutation (Davies et al, 2002). Several studies have reported a low incidence of Ras gene mutation in non-Hodgkin's lymphoma (NHL) (Ahuja et al, 1990). Although screening of $B R A F$ mutation in human tumours has widely been performed, to date the data on $B R A F$ mutation in NHL tissues is lacking. In the present study, we investigated the occurrence of BRAF gene mutations in NHLs.

*Correspondence: Dr SH Lee; E-mail: suhulee@cmc.cuk.ac.kr Received 28 April 2003; revised 30 July 2003; accepted 5 September 2003

\section{MATERIALS AND METHODS}

Paraffin-embedded tissues of human NHL were obtained from 164 patients. These samples were stained with haematoxylin-eosin, examined by immunohistology, and then classified according to the Revised European-American Lymphoma (REAL) classification (Harris et al, 1994). The NHLs analysed consisted of seven B-cell small lymphocytic lymphomas, three mantle cell lymphomas, four follicular lymphomas, 49 mucosa-associated lymphoid tissue (MALT)-type lymphomas, 67 diffuse large B-cell lymphomas, four precursor T-lymphoblastic lymphomas, one T-cell chronic lymphocytic leukaemia, 14 peripheral T-cell lymphomas, unclassified, 14 angiocentric lymphomas, and one intestinal T-cell lymphoma. Ethical committee approval for the study was obtained. Through the microdissection technique, we selectively procured tumour cells and corresponding normal cells from histological sections of the 164 NHLs. Briefly, malignant cells were selectively procured from haematoxylin and eosin-stained sections using a 30G1/2 hypodermic needle (Becton Dickinson, Franklin Lakes, NJ, USA) affixed to a micromanipulator, as described previously (Lee et al, 1998). We also microdissected normal cells and used them for corresponding normal DNA. This microdissection technique used in this study has been proved to be precise and effective for procurement of tumour cells without normal cell contamination (Lee et al, 1998). DNA extraction was performed by a modified single-step DNA extraction method, as described previously (Lee et al, 1998).

Genomic DNA each from normal cells or tumour cells was amplified with two primer pairs covering exons 11 and 15 of $B R A F$ gene, because all of the BRAF mutations have been so far detected in exons 11 and 15 that encode the kinase domains in G-loop and the activation segment of BRAF, respectively. Radioisotope was incorporated into the PCR products for detection by autoradiogram. The PCR reaction mixture was denatured for $1 \mathrm{~min}$ at $94^{\circ} \mathrm{C}$ 
and incubated for 30 cycles. Other procedures of polymerase chain reaction (PCR) and single-strand conformation polymorphism (SSCP) analysis were performed as described previously (Shin et al, 1999). After SSCP, DNAs showing mobility shifts were cutout from the dried gel, and reamplified for 30 cycles using the same primer

A

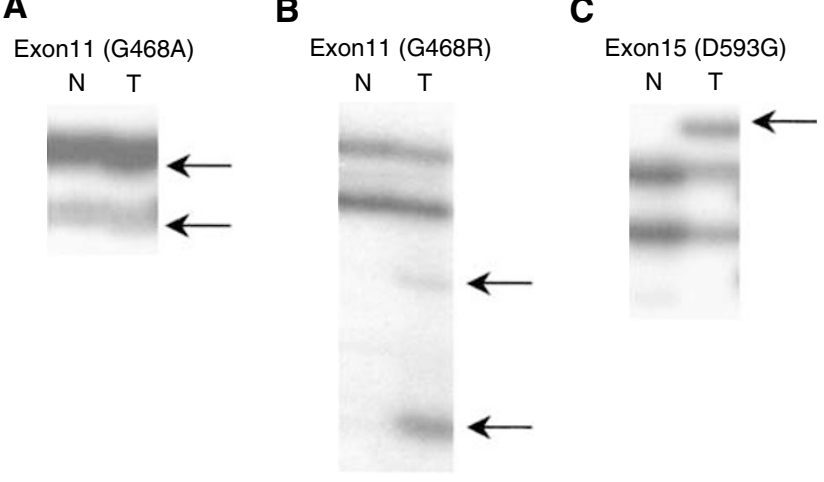

D

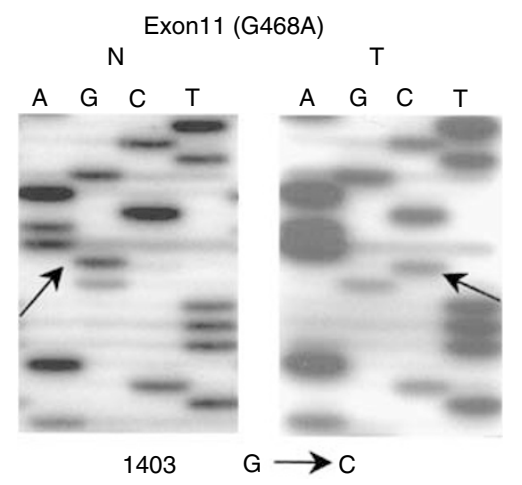

$\mathbf{E}$

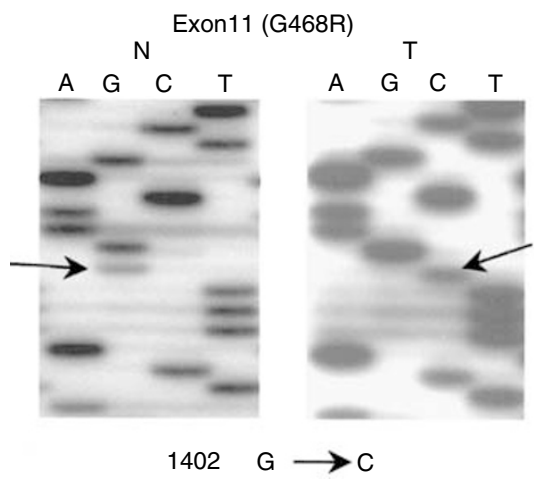

$\mathbf{F}$ sets. Sequencing of the PCR products was carried out using the cyclic sequencing kit (Perkin-Elmer, Foster City, CA, USA) according to the manufacturer's recommendation.

\section{RESULTS}

SSCP analysis of BRAF identified four aberrant bands (Figure 1). Enrichment and DNA sequence analysis of these aberrantly migrating bands led to the identification of four $B R A F$ mutations $(2.4 \%)$ (Figure 1). All of the four BRAF mutations were observed in diffuse large B-cell lymphomas (6.0\% of the 67 cases). Although $B R A F$ mutations were detected only in diffuse large B-cell lymphomas, this relationship was not statistically significant $(P>0.05)$. Three of the four BRAF mutations involved codon 468 (two G468R and one G468A) in the G-loop domain, and the remaining one was found at codon 593 (D593G) in the activation segment domain (Table 1, Figure 1). None of the corresponding normal samples showed evidence of mutations by SSCP (Figure 1), indicating the mutations detected in the specimens had risen somatically. We repeated the experiments two times, including tissue microdissection, PCR, SSCP and sequencing analysis to ensure the specificity of the results, and found that the data were consistent (data not shown).

\section{DISCUSSION}

Whereas the malignant melanoma is the most common tumour with BRAF mutations (roughly 60\%), this tumour is known to possess a much lesser frequency of RAS mutations. Such differential occurrences of $B R A F$ and $R A S$ mutation in some human cancers led us to analyse BRAF mutation in NHL in which $R A S$ mutation is known to be an uncommon event. We found that $B R A F$ gene is somatically mutated in NHLs, indicating that RAS RAF kinase pathway in some NHLs may be regulated by somatic mutations of $B R A F$. Despite the low frequency of $B R A F$ mutation in NHL compared with that of malignant melanoma, our data suggest that alteration of RAS-RAF kinase pathway by $B R A F$ mutation may play an important role in NHL carcinogenesis.

In the present study, none of the BRAF mutations involved the amino acid V599. The data are quite contrast to those of malignant melanomas, where approximately $90 \%$ of BRAF mutations involved V599, raising the possibility that the contribution of $B R A F$ mutations in the development of NHL might be different from that of malignant melanoma. Additionally, three (two G468A and one G468R) of the four BRAF mutations in this study involved the same amino acid (G468) that is located in the GXGXXG motif within the G-loop of the kinase domain. The G468A mutation was proven to be an activating mutation by the kinase assay and the transformation assay (Davies et al, 2002). For G468R, a novel $B R A F$ mutation, its functional implication is not known at this

\section{4}

Figure I BRAF gene mutations in $\mathrm{NHLs}$. SSCP $(\mathbf{A}-\mathbf{C})$ and DNA sequencing analyses (D-F) of DNA from tumours (lane $T$ ) and normal tissues (lane N). Exon II (A, B) and exon I5 (C) of BRAF were amplified. SSCPs of DNA from the tumours show wild-type bands and additional aberrant bands (arrows) as compared to SSCP from normal cells from the same patients. (D) Sequencing analysis from the aberrant band in (A). There is a $G$ to $C$ transversion at nucleotide I403 of BRAF (arrow) in tumour tissue as compared to normal tissue. (E) Sequencing analysis from the aberrant band in (B). There is a $\mathrm{G}$ to $\mathrm{C}$ transversion at nucleotide 1402 of BRAF (arrow) in tumour tissue as compared to normal tissue. (F) Sequencing analysis from the aberrant band in $(\mathbf{C})$. There is an $A$ to $G$ transition at nucleotide 1778 of BRAF (arrow) in tumour tissue as compared to normal tissue. Numbering of cDNA of BRAF was made in respect to the ATG start codon (GenBank). 
Table I Summary of BRAF mutations identified in the NHLs

BRAF mutations

\begin{tabular}{llll}
\hline Nucleotide & $\begin{array}{l}\text { Amino } \\
\text { acids }\end{array}$ & Anatomical site & \multicolumn{1}{c}{ Histologic type } \\
\hline GI403C & G468A & Cervical lymph node & Diffuse large B-cell lymphoma \\
GI403C & G468A & Cervical lymph node & Diffuse large B-cell lymphoma \\
GI402C & G468R & Tongue mucosa & Diffuse large B-cell lymphoma \\
AI778G & D593G & lleum & Diffuse large B-cell lymphoma \\
\hline
\end{tabular}

stage. In one NHL, we also found D593G BRAF mutation that has also been detected in colon tumours previously.

\section{REFERENCES}

Ahuja HG, Foti A, Bar-Eli M, Cline MJ (1990) The pattern of mutational involvement of RAS genes in human hematologic malignancies determined by DNA amplification and direct sequencing. Blood 75: $1684-1690$

Bos JL (1989) ras oncogenes in human cancer: a review. Cancer Res 49: $4682-4689$

Brose MS, Volpe P, Feldman M, Kumar M, Rishi I, Gerrero R, Einhorn E, Herlyn M, Minna J, Nicholson A, Roth JA, Albelda SM, Davies H, Cox C, Brignell G, Stephens P, Futreal PA, Wooster R, Stratton MR, Weber BL (2002) BRAF and RAS mutations in human lung cancer and melanoma. Cancer Res 62: $6997-7000$

Davies H, Bignell GR, Cox C, Stephens P, Edkins S, Clegg S, Teague J, Woffendin H, Garnett MJ, Bottomley W, Davis N, Dicks E, Ewing R, Floyd Y, Gray K, Hall S, Hawes R, Hughes J, Kosmidou V, Menzies A, Mould C, Parker A, Stevens C, Watt S, Hooper S, Wilson R, Jayatilake H, Gusterson BA, Cooper C, Shipley J, Hargrave D, Pritchard-Jones K, Maitland N, Chenevix-Trench G, Riggins GJ, Bigner DD, Palmieri G, Cossu A, Flanagan A, Nicholson A, Ho JW, Leung SY, Yuen ST, Weber BL, Seigler HF, Darrow TL, Paterson H, Marais R, Marshall CJ, Wooster R, Stratton MR, Futreal PA (2002) Mutations of the BRAF gene in human cancer. Nature 417: $949-954$

Downward J (2003) Targeting RAS signalling pathways in cancer therapy. Nat Rev Cancer 3: $11-22$

Harris NL, Jaffe ES, Stein H, Banks PM, Chan JK, Cleary ML, Delsol G, De Wolf-Peeters C, Falini B, Gatter KC, Grogan TM, Isaacson PG, Knowles DM, Mason DY, Muller-Hermelink HK, Pileri SA, Piris MA, Ralfkiaer E, Warnke RA (1994) A revised European-American classification of
The most impressive examples of recent cancer therapies used protein kinase inhibitors such as Imanitib (Gleevec) (Downward, 2003). Since RAS-RAF-MEK-ERK-MAP kinase pathway is activated by protein kinase, therapies that target this signalling pathway would therefore be very valuable in treating tumours that have activating mutations of BRAF. In this respect, the present study may provide the possibility of therapy targeting mutated BRAF in NHL.

\section{ACKNOWLEDGEMENTS}

This work was supported by the MRC funding from KOSEF through the Cell Death Disease Center at the Catholic University of Korea (R13-2002-005-01004-0). lymphoid neoplasms: a proposal from the International Lymphoma Study Group. Blood 84: $1361-1392$

Lee JY, Dong SM, Kim SY, Yoo NJ, Lee SH, Park WS (1998) A simple, precise and economical microdissection technique for analysis of genomic DNA from archival tissue sections. Virchows Arch 433: 305-309

Naoki K, Chen TH, Richards WG, Sugarbaker DJ, Meyerson M (2002) Missense mutations of the BRAF gene in human lung adenocarcinoma. Cancer Res 62: 7001-7003

Pollock PM, Harper UL, Hansen KS, Yudt LM, Stark M, Robbins CM, Moses TY, Hostetter G, Wagner U, Kakareka J, Salem G, Pohida T, Heenan P, Duray P, Kallioniemi O, Hayward NK, Trent JM, Meltzer PS (2003) High frequency of BRAF mutations in nevi. Nat Genet 33: 19-20

Rajagopalan H, Bardelli A, Lengauer C, Kinzler KW, Vogelstein B, Velculescu VE (2002) Tumorigenesis: RAF/RAS oncogenes and mismatch-repair status. Nature 418: 934

Satyamoorthy K, Li G, Gerrero MR, Brose MS, Volpe P, Weber BL, Van Belle P, Elder DE, Herlyn M (2003) Constitutive mitogen-activated protein kinase activation in melanoma is mediated by both BRAF mutations and autocrine growth factor stimulation. Cancer Res 63: 756759

Shin MS, Park WS, Kim SY, Kang SJ, Song KY, Park JY, Dong SM, Pi JH, Oh RR, Lee JY, Yoo NJ, Lee SH (1999) Alterations of Fas (Apo-1/CD95) gene in cutaneous malignant melanoma. Am J Pathol 154: 1785-1791

Yuen ST, Davies H, Chan TL, Ho JW, Bignell GR, Cox C, Stephens P, Edkins S, Tsui WW, Chan AS, Futreal PA, Stratton MR, Wooster R, Leung SY (2002) Similarity of the phenotypic patterns associated with BRAF and KRAS mutations in colorectal neoplasia. Cancer Res 62: 6451-6455 